\title{
Screening the Author: The Literary Biopic
}

SHACHAR, HILA. 2019. Screening the Author: The Literary Biopic. Palgrave Studies in Adaptation and Visual Culture. Switzerland: Palgrave Macmillan.

Reviewed by GIRISH N

Films based on the biography of literary figures (literary biopics) have started to gain considerable reputation and critical acclaim. Hila Shachar draws our attention to such a boom of literary biopics which have secured a unique position in the contemporary cinematic representations in connection with certain cultural developments. They have emerged as distinct film genre, and earlier literary biopics formed only a fragment of the subgenre in the general biopic, adaptation and heritage film. The critical appreciation on these films was scanty except the works of Judith Buchanan and Bronwyn Polaschek. Shachar studies literary biopics using two main approaches. She studies how biographies of popular authors in Western culture are adapted onto the film within the methodological framing of genres of cinema and tropes of the screen and by analysing the persona of the author from the ideological, cultural, industrial and economic preoccupations.

In Chapter 2 entitled, "Heritage and the Literary Biopic 'Template': Shakespeare, Austen, Wilde, and the Author as Product," Shachar distinguishes literary biopic from the heritage films and through a close analysis of Becoming Jane, Shakespeare in Love and Wilde fleshes out the key aspects which form the template of these films and theorise the dominant tropes of authorial identity in these films. Both Becoming Jane and Shakespeare in Love are filled with "Aestheticized views of desk, quill, parchment, inkpot, typewriter, the writer in a moment of meditative pause" which form significant imagery forming the template of literary biopic. But Wilde according to Shachar situates itself in the 
opposite end to the said films. It appropriates the author "as a public persona" and explores "specific and contextualised social, ideological, and radical issues (43)." Despite the film portrays Oscar Wilde as an iconic literary personality, it doesn't portray him as mini-god for worship, instead it represents cultural debates, and political ideologies around the life of the author. The film through complex symbolic visual representations depicts Wilde as the queer martyr who sacrificed everything like a female muse.

Shakespeare in Love goes beyond the regular barriers of a literary biopic film by involving the elements of postmodernism. The film "provides a pastiche of anachronistic historical and contemporary perspectives, and mines the past through a highly self-conscious, playful, and knowing sensibility-for all its postmodern hijinks and intertextual allusions". The film by "mingling of Hollywood marketing, modern capitalistic branding, postmodern consciousness, and historical and heritage inheritance" reverses the "authorial body, the authorial spirit, the authorial genius, and the authorial cultural identity" (33) by locating the ideological and cultural discourses within the body of the 'brand'Shakespeare. Wilde on the other hand continues to exist within this heritage and biopic mode. The tropes of being writer are replaced with the images of his writing being stopped by the prison guard and his pen and paper are taken away. The film uses the trope of the 'wounds of love' to portray Wilde as ideologically feminised author. He is associated with saintly, martyred imagery that is usually associated with in the literary biopics of female authors. The film argues, "Love is here not a healer or fixer, but an appropriated politicised exploration of marginalised sexual identity" (49).

"The Muse Speaks Back: Silence, Invisibility, and Reframing Authorial Identity," chapter 3 studies four screen adaptations: 
The Invisible Woman, The Edge of Love, Bright Star, Walk Invisible with a special focus on 'love story,' an important trope of the literary biopic. These films not only portray love relationships from the point of sexual desire, but also from the point of view of familial bonds. There is an inherent feature in these films that they tell the author's story through "unacknowledged narratives of those who sit on the margins of history and creativity...and explore authorial biography, subjectivity, and identity from such a position are selfconscious reworking of the individual subjects." The chapter establishes the ways in which recent literary biopics challenge the invisible position of the muse by portraying the years and moments of both the author and the muse where the muse's influence can be best explored.

Although Bright Star represents the life of John Keats sensitively and favourably, it is not only his story that is being told. The film places Fanny Browne, the muse of Keats in the centre of filmic narrative whose "creative artistry competes with Keats's own creation of his poetry" (66). The director performs the process of historical recovery of the marginalised narrative and critically juxtaposes the persona of Keats. Using the theme of 'sewing,' Fanny is portrayed as a feminist artist. In all the important scenes throughout the film are punctuated by "Fanny's internal and creative of world of sewing," by doing so "she is also creating her own marginal artwork" and her interior struggle and grief gets manifested "itself through an immediate response to create something to sew." Fanny's generative power takes the centre stage of the film with "smaller glimpses of Keats's own creative process in the periphery" (68).

Chapter 4, "Feminine Authorial Mournings: The Female Writer on Screen and the Trauma of the Present" interprets literary biopics of female writers with a recurrent theme of 
grief and mourning, death, madness, suicide etc. The films being discussed are The Hours and Life in Squares on Virginia Woolf and the Bloomsbury group, Sylvia on Sylvia Plath, Iris on Iris Murdoch, and An Angle at My Table on Janet Frame. On the one hand these films portray how stereotypes and themes of western culture have traditionally coded the authorial body and on the other hand "explore issues of individuality...so to explore just how we use the authorial body as a national, cultural, and quasireligious signifier of decline and change" (99-100). The said films extend the misogynistic and historical understanding of "women as unstable bodies with unstable identities" and reduce the creative expression of the authors with a simple explanation of author's being preoccupied "with stereotypical female 'madness', where women are not agents of their art, but are the passive victims of inner turmoil."

The representation of women writers in these films follow masculine definition of authority and control on the body and mind of the male writers. All three writers in these films as Sonia Haiduc argues "fall prey to their inner demons of selfdestruction and the shackles of mental illness. Madness and suicide plague the characters (101)." The films use abundant images of trauma, grief, mental decline and suicidal tendencies of the writers which as the author rightly argues comes straight from the clichéd representation of women in the nineteenth century. The Hours and Sylvia are portrayed as sick women of art who perfectly in contrast with "Victorian angel of the house who is sexually dead/pure". The female writers declining into madness appears right at the start of the films "thereby cementing the link between their works and 'madness' and defining their biographies as ones primarily shaped by mental illnesses" (102). 
Chapter 5 entitled, "Appropriating the Beats, Radicalising the Literary Biopic: Intersectional Politics and Ginsberg and Kerouac on Screen" discusses the spiritual and personal lives of American Beat authors. The chapter poses important questions on their spiritual renewal, cultural 'death', gender, sexuality, and economic realities. Films that are explored in the chapter include, Kill Your Darlings, Howl, On the Road, and Big Sur. These films are experimentative in nature since they depart from the screen conventions of Hollywood, and are not intended to regular film audiences, therefore they "sacrifice a more straightforward narrative, structure, and use of genre in order to experiment with form and ideology." Kill Your Darlings and Big Star highlight "deliberately 'unsexy' and complex religious thought that infused the writing, ideologies, and philosophies of Beat authors such as Allen Ginsberg and Jack Kerouac.

Kill Your Darlings avoids clichéd scenes in which the author smoking cigarette and using type writer; instead it focuses more on the complex nature of Ginsberg which showcases "his contradictory and complex relationship with religious philosophy and identity". The film is preoccupied with the representation of "the 'soul' and 'spirit' of past and present America as mediated via Ginsberg's body and self, and his Jewish identity as well". Big Sur similarly portrays the "'unsexy' moment in Jack Kerouac's life, when he began to remove himself from his celebrity Beat image and deteriorate into alcoholic solipsism that rings as distinctly unattractive, unromanticised, and unpleasant to contemplate on screen, despite all the film's visual use of sublime landscape scenes." Both the films don't follow typical biopic tradition of representing the authors by dealing with issues which are conventionally not marketable in Hollywood films. Instead these are "pinned in the earthly realm of history, home, university, city, and natural landscape, move both outward and 
Girish N

inward in their ideological politics and philosophical investigations of the American 'soul' in both past and present, using authorial identity and bodily presence as a way to navigate such collective concerns" (132).

Hila Shachar's Screening the Author: The Literary Biopic is a pioneering attempt in the representation of literary authors on the screen. The author draws heavily from the conventional biopic and heritage film genre and argues that there is a scope for establishing 'literary biopic' as a unique and full-fledged genre. She studies the biographies of William Shakespeare, John Keats, Jane Austen, Oscar Wilde, Iris Murdoch, Sylvia Plath, Virginia Woolf, Allen Ginsberg, Jack Kerouac, and analyses the ways in which these authors appear predominantly on the silver screen. 